\title{
Muslim Bodies in the Metropole: Social Assistance and "Religious" Practice in Interwar Paris
}

\author{
Naomi Davidson \\ Introduction
}

This paper examines the interwar origins of Muslim histories in metropolitan France. It argues that the seeds for the racialization of people identified as Muslim in France were laid during this period with the creation of a mosque and other "Muslim" sites in Paris. By examining the creation and management of these Muslim spaces by French officials and North African religious leaders we are able to write a transnational history of Islam in Europe, one that acknowledges Islam's long presence in European social and political life. In acknowledging not only the role of French colonialism, but also that of Muslim leaders and by elaborating on what I call "French Islam," we discover how this collaborative construction of a particular vision of Islam ultimately contributed to the process of essentializing those people identified as "Muslim."

I examine the Paris Mosque (Mosquée de Paris) and the Franco-Muslim Hospital (Hôpital Franco-Musulman), built between 1922 and 1935, in order to understand the elaboration of this particular vision of French Islam that blended "Muslim" and "French" civilizations. French Islam inscribed Islam firmly within a French republican model, yet it simultaneously maintained Islam outside the boundaries set by French secularism. The architectural and aesthetic plans for the Mosque, as well as the events that marked the milestones in its development, were essential to the creation and diffusion of French Islam. In this paper I argue that the social service and policing programs that emerged as satellites of French Islam's most important site, the Paris Mosque, used Islam as the basis for their differential treatment of North Africans. In doing so, they set in motion a pattern in which the segregation of immigrants from the Maghrib was portrayed as protective and as preferential treatment based on religious difference. In other words, it was the panoply of interwar social programs that depended on the establishment of the Paris Mosque that helped establish Muslims as only and eternally Muslims in metropolitan France. 


\section{Building the Paris Mosque, Building French Islam}

In the aftermath of World War I, French social scientists, orientalists, and politicians began to articulate a vision of Islam, and Muslim practices, that they hoped would communicate Paris' respect for and commitment to its empire's Muslim subjects. This vision, which I call French Islam, blended French republican principles with French understandings of Sunnī Islam as practiced in Morocco, and emphasized the embodied practices they argued were integral to the proper performance of Muslim religious ritual. The French emphasis on these embodied religious practices transformed an ostensibly religious identity into a racialized one over the course of the twentieth century. At the center of the story of this process of racialization is the Paris Mosque, a "cathedral" mosque built in the immediate aftermath of World War I by metropolitan and colonial leaders in cooperation with a transnational Muslim elite. The Islam embodied by the Paris Mosque served as the exclusive medium for the French state's management of its interactions with Muslim subjects residing in the metropole during the 1920 s and 1930 .

The Paris Mosque and its Muslim Institute were first conceived as a war memorial to be built in the shadow of Les Invalides, where the French army honored its greatest military heroes. Locating the complex near France's shrine to its military victories was intended to reflect the sacrifices made by North and West African colonial soldiers during World War I, as well as to render the complex easily accessible to elite Muslims visiting Paris. The architecture of this "durable monument" was expected to conform to the "artistic demands" of a grand capital. ${ }^{1}$ When the ground for the construction site was broken six years later, in the $5^{\text {th }}$ arrondissement across from the city's natural history museum, the site had been reimagined as a reproduction of a mosque in $\mathrm{Fez}$ that would be built alongside French civilization's most hallowed institutions of learning rather than the shrine to its military successes. The Paris Mosque was not merely a religious site, it was a monument to France's power in the Muslim world, built to reflect its vision of Islam and Muslims. As such it was a "repositor[y] of meaning" where a wide range of events inscribed France's relationship with its Muslim subjects on a daily basis. ${ }^{2}$ The placement of the Mosquée's complex in the cradle of French civilization, and its "Muslim

1 "Une Mosquée à Paris," Ministère des Affaires Etrangères, Direction des Affaires Politiques et commerciales, 22 September 1916, SHAT 7 N 2104, Divers 1916-1917. This text, particularly the above citation, is drawn from Paul Bourdarie's "L'Institut Musulman et la Mosquée de Paris," La Revue Indigène (Oct.-Nov. 1919).

2 Daniel Sherman, The Construction of Memory in Interwar France (Chicago: University of Chicago Press, 1999), 216. 
architectural character" visually signaled the tension between its role as a secular cultural and religious institution that defined the paradox of French Islam.

The two sites were the fruits of contentious collaboration involving the Ministry of the Interior, the Ministry of Foreign Affairs, the Ministry of War, the city of Paris, and the colonial and protectoral administrations of Algeria, Morocco, Tunisia, and French West Africa. Importantly, in addition to the metropolitan and colonial administrations, a group of elite Muslims from the Maghrib and West Africa participated in the elaboration of this project. This group, known as the Society of Habous and Sacred Places of Islam (Société des Habous et des lieux saints de l'Islam), was headed by the Algerian-born Abdelkader ben Ghabrit, more commonly known as Si Kaddour. Si Kaddour was awarded the leadership of the group, and thus, of the Mosque and Institute, not because of his theological erudition or history of religious leadership. Rather, his presidency depended on the political connections he had made in Resident General Lyautey's Moroccan protectorate through his tenure as the sultan's master of protocol. It is thus important to note that $\mathrm{Si}$ Kaddour and the other Muslim leaders who participated in the creation of French Islam were not necessarily well-regarded by their fellow Muslims, on either side of the Mediterranean.

This collaborative vision of French Islam, a system of belief and ritual that was at once particular to Muslim civilization but compatible with French republican ideals and secularism, was to be instantiated in the site of the Paris Mosque. For French connoisseurs of Islam, it was in Morocco that this "rejuvenated Islam" originated from an Islam magnificent in "its isolation, its archaism, which...brings it closer to the purest [Muslim] belief." This purest form of Islam existed in a country that, through its encounter with "modern life," was "adapting to progress" with France's help. ${ }^{3}$ Moroccan Resident General Lyautey argued that this encounter was possible because Morocco and France were both civilizations that respected their ancient traditions while being open to progress. Like the French, he explained, the Moroccans had "an enlightened bourgeoisie...very concerned with progress, most especially economic progress." ${ }^{4}$ But in addition to these similarities between elites on both sides of the

3 René Weiss, Récéption à l'Hôtel de Ville de Sa Majesté Moulay Youssuf, Sultan du Maroc, Inauguration de l'Institut Musulman et de la Mosquée de Paris (Paris: Imprimerie Nationale, 1927), 2, XXv.

4 Ibid., 36. President Doumergue also celebrated the friendship between "the Muslim elite and the French elite" in his speech. At no point in the creation of the Mosquée were non-elite Muslims on either side of the Mediterranean taken into account, other than that they were solicited for donations. As we will see, this was one of the reasons the Mosquée was critiqued by nationalist leaders. 
Mediterranean, proponents of the Mosque argued that Islam and French republicanism shared many traits. Si Kaddour asserted that "respect for morality" and the "glorification of charity" were principles dear to both Islam and a French civilization whose greatest concern was equality. ${ }^{5}$ French President Doumergue made the link between the philosophical underpinnings of French and Muslim culture more explicit:

[Equality] ...of human consciences and of their sincere impulses, is the mark of our democracy; the Muslim savants, as we know, have exalted the respect of individual dignity and human liberty. They have called for...the reign of a large fraternity and of equal justice. Democracy has no fundaments other than these. ${ }^{6}$

There was a clear attempt to identify Islam as compatible with democracy, tolerance, equality, and individual liberty.

It was the Mosque, rather than the Institute, that did the work of remaining bound to "Muslim" tradition as filtered through French perceptions of Moroccan Muslim aesthetics and practices. When its proponents discussed the Mosque's creation, they did not situate it in the heart of Paris's university district: that was the space occupied by the Muslim Institute, whose Islam was intellectual, modern, and compatible with French republicanism but whose physical design was never described. The Mosque, on the other hand, was not discursively located in a particular part of Paris, other than in its center. Although it was necessary that the site be visible to visitors in Paris' landscape, its geographical location was far less emphasized than its design. Its aesthetic character was of primary importance because the Mosque represented an Islam that its French proponents believed had a "hold on its faithful" and controlled all aspects of their lives. It required of its believers that they perform certain practices in particular settings because of the inextricable link between religious practices and daily life. ${ }^{7}$ Its architects hoped to ensure the Mosque's appeal to Muslims by designing it in a "Moroccan" style that would respond to their aesthetic ideals, although contemporary observers were quick to point

5 Si Kaddour's speech at the Mosquée's groundbreaking ceremony, cited in Weiss, Récéption à l'Hôtel de Ville de Sa Majesté Moulay Youssef, 49.

6 Doumergue's speech at the groundbreaking ceremony, ibid., 70.

7 Letter from Saint Aulaire to Ministre des Affaires Etrangères, 7 January 1916, AN Fonds Lyautey 475 AP/95/Lettres au département 1916. See also Commissariat Général à l'Information et à la Propagande. "Projet de loi relatif à l'édification à Paris d'un Institut Musulman" (undated), AMAE Afrique 1918-1940/Affaires musulmanes/11. 
out its appeal to Parisian and other tourists, comparing it both to tourist attractions in North Africa and metropolitan expositions and fairs.

The Mosque's architects chose to give the building the "traditional hispanomauresque" style in vogue among Lyautey's Service des Beaux Arts architects in the Moroccan protectorate. ${ }^{8}$ It was in Morocco, critics agreed, that "a new architecture [was] born... [a] collaboration between French science and intelligence with indigenous craftsmanship and tradition."9 In October $1920 \mathrm{Si}$ Kaddour met with architects in Rabat who specialized in buildings with "Muslim character," in order to prepare the preliminary plans for the Mosque and its annexes. ${ }^{10} \mathrm{~A}$ few months later, he reported back to the Ministry of Foreign Affairs that the Moroccan members of the Society of Habous had unanimously decided that the Mosque should have "an African architectural character" and, more specifically, that it should be modeled on Fez's fourteenth-century mosque-madrasa Bou Inania. Sultan Abou Inan hoped to reorient the city's religious geography by building the complex near the boundary between the old and new cities and thus drawing people away from some of the older mosques. Yet although the Inspector of Beaux Arts wrote that the site was "undoubtedly the biggest and most sumptuous [mosque] of all Morocco," its decoration was not as refined and artistic as that of Fez's older mosques." The sources that refer to the decision to use Bou Inania as the model for the Mosque complex mention the physical beauty and renown of the Fassi site but do not refer to its founder's attempt to remake his city's religious landscape or to the site's relative aesthetic weakness compared to older mosques. It would be intriguing to know whether they were conscious of the ramifications of their choice of this particular institution as a model for Paris's mosque.

Once this model had been chosen, the French architects were given blueprints of this famous institution to inspire their first attempts at plans for the Parisian mosque, whose layout is clearly based on that of Bou Inania. ${ }^{2}$

8 The Mosquée's original plans were drawn by the former director of the Service, Maurice Tranchant de Lunel, and another member, Maurice Mantout, was part of the team whose design was ultimately used.

9 Henri Descamps, L'Architecture moderne au Maroc (Paris: Librairie de la Construction moderne, 1931), 1.

10 Letter from Si Kaddour to Leygues, 6 October 1920, AMAE Afrique 1918-1940/Affaires musulmanes/11.

11 Didier Madras and Boris Maslow, Fès, Capitale artistique de l'Islam (Casablanca, Morocco: Editions Paul Bory, 1948), 134-135.

12 Letter from Si Kaddour to Leygues, 27 December 1920, AMAE Afrique 1918-1940/Affaires musulmanes/11. One of the Mosquée's architects, Mantout, also wrote to Leygues to tell him that the Mosquée was inspired by "one of the most beautiful specimens of Moroccan 
This resonated with metropolitan architectural critics, one of whom noted approvingly that "Muslim constructions, unlike ours, have not evolved and must, on the contrary, remain traditional."13 Lyautey's Morocco was a virtual laboratory for modernist architecture and urbanism in a colonial setting, as Gwendolyn Wright has argued. Under his residency, the Service des Beaux Arts instituted an energetic campaign to preserve entire districts, virtually freezing Moroccan medinas in time, and to "restore" and "reproduce" monuments and other sites that had fallen into disrepair. Wright also argues that the Service, especially under the leadership of Tranchant de Lunel, "oriented itself towards charming streetscapes that would appeal to French residents and tourists." ${ }^{14}$ The architectural style of the Mosque and the fact of it being built to recreate, as closely as possible, a specific Moroccan religious site at once identified Islam as immutable and unchanging and turned the building into a spectacle to be enjoyed by non-Muslim Parisians. ${ }^{15}$

The popular press quickly touted the tourist potential of the Mosque. One observer wrote in the Catholic journal En Terre d'Islam of the "veritable enchantment" of the Paris Mosque: "in penetrating these courtyards and richly decorated rooms, one has more of an impression of visiting a museum than of entering a place of prayer."16 The reference to visiting a museum is important, for despite the intentions of the Mosquée's founders that the site serves a purely pedagogical function, many Parisians viewed it as a site for the display and consumption of Islam. In fact, the Mosque also bore some

architecture." See, in the same box, Maurice Mantout, "Note descriptive de la Mosquéeet de ses dépendences," 12 August 1922.

13 Antony Goissaud, "L'Institut musulman et la Mosquée de Paris," La Construction moderne 3 (2 November 1924), 52 .

14 Gwendolyn Wright, The Politics of Design in French Colonial Urbanism (Chicago: University of Chicago Press, 1991), 134.

15 As Justinard put it in his thesis on the Mosquée, “Isn't it...paradoxical that it's easier for a Christian who wants to see a Muslim religious building to penetrate a mosque in Paris than in North Africa, where most mosques are closed to non-Muslims?" Here an analogy is made between the situation in Morocco (where under Lyautey's protectorate mosques were "protected" from visits by non-Muslims) and that of the rest of the territory. The refusal to allow non-Muslims to enter mosques is not a feature of Islam and was not even applied uniformly in the French empire. However, it is instructive that Justinard made this remark, for many of the tourists who visited the Mosquée may well have been disappointed by their inability to do so in Morocco and hoped to see "the same thing" back home. Pierre Justinard, "La Mosquée de Paris" (MA thesis, Ecole nationale de la France d'outre-mer, 1944), 57 .

16 Georges Buchet, “La Mosquée de Paris," En Terre d'Islam 34 (January 1930), 30. 
resemblance to the colonial expositions, although unlike the exhibits constructed there, the Mosque was set in Paris's landscape permanently and could be visited again and again. The very mosaics used to adorn the site had appeared at the Moroccan pavilion at the 1922 Colonial Exposition in Marseille, as a gift from Lyautey. ${ }^{17}$ One newspaper promised its readers, in its review of the Mosque, "it will provide a change for Parisians from the cardboard boxes with which one pretends to convey, in expositions, the splendor, the mysterious charm of the intimacy of African houses."18 L'Illustration urged those who had traveled in the Muslim world to visit the Mosque in order to experience anew their memories of the food and decor they had so enjoyed. ${ }^{19}$ From the beginning, the Mosque's founders planned to charge non-Muslim visitors admission to the site; this contributed even more to the idea that it was an exhibit to be consumed publicly. Fresh from their success, the Mosque's architects went on to design both the North African pavilions of the $193^{1}$ Colonial Exposition and the Franco-Muslim Hospital in Bobigny that opened in 1935; its façade greatly resembled the Mosque's aesthetics. Clearly, in many peoples' minds, the Mosque was the highlight of a set of sites around the capital that provided visitors with an exoticized image of Islam and Muslims.

The events organized by the French state in collaboration with Si Kaddour and the colonial administrations contributed to the creation of a "secular" Islam in the sense that "religious" events were folklorized, rendered public, and emptied of their original significance, all the while ostensibly occupying the central space of the Mosque's activities. The ceremonies surrounding the Mosque's landmark moments (the groundbreaking, orientation, and inauguration) served as a way to mark both the place of the complex in Paris's geography of significant monuments and the relationships among metropolitan, colonial, and Muslim dignitaries. In addition to these landmark events associated with milestones in the Mosque's construction, other occasions also served as opportunities to shore up metropolitan and colonial relations, particularly with Morocco. A note from the police dated 26 June 1930 reports that a "Fête de charité "Nord-Africaine" ("North African" Charity Event) would take place in the Mosque's confines the following day, under the patronage of the wife of

17 Additional mosaics were required, and Si Kaddour organized for them to be transported from Morocco. In addition, he successfully argued that it was necessary to bring Moroccan artisans to Paris to complete the decoration of the site. See letter from Si Kaddour Ben Ghabrit to Poincaré, 13 March 1923, AMAE Afrique/Affaires musulmanes/12.

18 Le PetitJournal, 25 February 1922.

19 “Un décor d'Orient sous le Ciel de Paris," L'Illustration (26 November 1926), 582. 
Morocco's resident-general. The soirée was designed to raise funds for the Red Cross's work with the indigènes, or Muslim "natives."20 The Mosque was also a privileged site for drawing the Moroccan elite, especially the young generation, closer to France. Even before the site was completed, it was an important stop during tours of Paris taken by Moroccan students. During a 1923 visit, students followed an "interesting" visit to the museum at the Botanical Garden with a tour of the construction site led by one of the Mosque's three architects. The group's leader noted that "we recognized many of Fez and Meknes' master mosaicists, who offered us mint tea." By 1925, the students were apparently "thrilled" with "this corner of Morocco, completely charming with its patios, gardens, water jets, beautiful galleries" and proud that "European visitors do not hide their admiration."21

The events designed to showcase the Mosque also highlight that it was built in the French capital during a period in which metropolitan-colonial questions were particularly fraught. Nowhere is the local battle to place Paris at the heart of the French empire more evident than in Paris City Council Member Pierre Godin's campaign in support of the city celebrating the centenary of the conquest of Algeria. Although his omission of the Mosque itself as a site contributing to Paris's importance in the colonial Muslim world is shocking, his comments about the relationship between the city and the North African colonies are important to understand the space the Mosque occupied in the city as a synecdoche of France. For, as Godin argued, "Algeria is not only...a province of French thought, but an enthusiastic department of Parisian thought. And Paris is enchanted by its animating influence."22 Although he was primarily interested in bringing groups of students to Algeria to witness French progress in action, Godin also hoped to create Parisian venues for the exhibit of Algerian art, crafts and architecture, and literature. The celebration of the Mosque as a credit to Paris's cachet as the heart of the Muslim world certainly supports Gary Wilder's suggestion that we see Paris as "a fundamentally imperial city" in

$20 \quad$ Note from 26 June 1930, APP E ${ }^{\mathrm{b}} 125 /$ Aït el Kébir.

21 Paul Marty, "Mission d'étudiants marocains, août 1923" and "Voyage en France des Etudiants Marocains 1925," AN Fonds Lyautey 475 AP 171/13: Voyages des Marocains civils en France, juillet 1922.

"Note sur la participation de Paris aux manifestations du Centenaire de l'Algérie et sur les dispositions prises par la Commission du centenaire pour assurer cette participation conformément aux déliberations du Conseil Municipal des 11 juillet et $3^{1}$ décembre 1929, présentée par Pierre Godin, Conseiller Municipal, Président de la Commission Municipale du Centenaire de l'Algérie." Rapports et documents du Conseil Municipal de Paris, 20 March 1930. 
a metropole that was itself "the very center of an empire of which it and its colonies were integral parts." 23

The Paris Mosque, then, was the product of collaboration among the French state, colonial administrations, and a hand-picked group of North and West African Muslim elite men led by the Algerian-born Si Kaddour. ${ }^{24}$ It was very much a product of its time: fears of being eclipsed by England and Germany as a power in the Muslim world propelled France's metropolitan and colonial administrators into providing tangible evidence of their Muslim politics. The Muslim elites who acted as intermediaries between Muslims and the colonial administrations saw their participation as a way to prove their loyalty to France and increase their own prestige. Yet what began as a fairly straightforward political move in response to external threats quickly became something much more complex. The Mosque de Paris became the physical embodiment of a "new" Islam, one compatible with the principles of secularism and rational modernity while rooted in "traditional" Moroccan Islam. Although it was originally justified as a gesture of recognition for the sacrifices made by colonial soldiers, chance dictated that the Mosque would come to be built in the heart of the Latin Quarter. This allowed the Mosque's proponents to use the site as a theater for the display of French Islam: the Muslim Institute, whose intellectual character perfectly suited the neighborhood, celebrated the similarities between French and Muslim civilizations, while the Mosque's Moroccan-style architecture guaranteed the authenticity of the practices that would be performed in the building. The deeply rooted French belief that Islam was a religion in which materiality mattered much more than in any other faith made the choice of embodying this vision of Islam in a mosque a logical one.

Yet the idea that Muslim practice was intrinsically physical and invaded all aspects of everyday life, confounding the public and private spheres, also implied that the metropolitan and colonial administrators who favored the Mosque's construction did not believe that it was possible for Muslims to become modern, French, secular subjects. The state that separated church and state in the law of 1905 insisted on identifying its colonial subjects and protégés as inevitably and only Muslim. As we see in the following section, the

\footnotetext{
23 Gary Wilder, The French Imperial Nation-State: Negritude and Colonial Humanism between the Two World Wars (Chicago: University of Chicago Press, 2005), 28.

24 Interestingly, one notable Muslim supporter of the Paris Mosque project was Cheikh al-Alawī, renowned for his defense of Islam in the face of French colonialism. The founder of the Țariqqa 'Alawiyya movement was not an official member of Si Kaddour's committee, yet his support for the Paris mosque led him to attend its inauguration. He believed the institution could serve the interest of Muslims living in the metropole.
} 
ambiguity at the heart of French Islam informed the policy and social assistance programs designed contemporaneously with the Mosque to cope with the North African immigrant population of Paris.

\section{Muslim Bodies in French Spaces}

The construction of the Paris Mosque and the Muslim Institute gave body to the vision of French Islam as imagined by its proponents, but in the late 1920s, the question of how government support for French Islam would affect the lives of the primarily male, working-class North African residents of the capital was unclear. Metropolitan and colonial proponents of French Islam did not recognize the Islam practiced by many of these men as "true" Islam; their religious observances were characterized as akin to paganism. The disregard of metropolitan and colonial officials, social scientists, and the Muslim leaders chosen by French authorities, for the Muslim practices of certain North African immigrants in the Paris region was essential to their defense of French Islam. Immigrants to France during this period sometimes linked their Muslim practices to nationalist activity; or to social solidarity and mutual aid societies; yet others focused on cultural activities. But from the very beginning of the articulation of French Islam by French politicians and the elite Muslim members of the Society of Habous the possibility of Islam's multiplicity, of different ways of being Muslim, was foreclosed.

Upon their arrival in Paris North African immigrants quickly learned that they would be counted, professionally oriented, and healed as Muslims rather than simply as immigrant workers. With the Mosque as the central site of Muslim authority, the national and local administrations created a city- and suburban-wide network of Muslim sites designed to structure the lives of North African immigrant workers. Sites like the Bureau de la rue Lecomte, at once a social assistance office and a surveillance center, or the Franco-Muslim Hospital in the northeastern suburb of Bobigny were part of a network of separate social assistance services centered on Muslim religious identity and created for North African immigrants. The foundations for the French policy of administering North African immigrants exclusively as Muslims were thus laid at the same time as the creation of the Mosque itself. The tension between the promise of openness embedded in the logic of French Islam and the restrictiveness of Parisian Muslim institutions symbolizes the paradox at its heart. Although all immigrant workers during this period were subject to different legal regimes than were French citizens, the programs designed for North African Muslims set them apart from other immigrants, even other colonial 
immigrant workers. The rationale for this segregation was corporeal: the French belief in the centrality of embodied practices in the lives of Muslims meant that the kinds of services that were designed to assist North African immigrants took for granted that Muslim bodies had different demands than non-Muslim ones. The Franco-Muslim Hospital is the example par excellence of the state's contradictory impulses: while the construction of this hospital effectively "protected" Parisian public hospitals from what were seen as disease-ridden North African male bodies, some of its proponents also sincerely believed that they were providing Muslims with the space to engage in Muslim practices safely and securely. This corporeal logic of the 1920s and 1930s, couched in the language of religious protection, continued to influence French Muslim policy throughout the twentieth century.

North African immigrants were thus administered separately from other foreigners (even though Algerians were in fact French nationals, if not French citizens), and more importantly, they were administered as religious subjects. On the one hand, the state could be commended for providing them with religious services that may otherwise have been unavailable to them since there simply was not a longstanding Muslim community capable of providing religious sites for new immigrants. Yet on the other hand, by requiring them to make use of separate Muslim services, the French state made it impossible for Muslim immigrants to be anything but Muslim. The Ministry of the Interior simultaneously helped finance the salary of an imam to serve Paris's North African population and created a complex network of techniques for policing those same people. In the years immediately following World War I, war-era "Muslim" organizations resurfaced in new forms, of which the more important was Service des Affaires Indigènes Nord-Africaines (The North African Native Affairs Service, or SAINA), created in 1928. The SAINA, controlled by the Préfecture of the Seine and the Préfecture of Paris, was directed exclusively at the capital's North African population. The cornerstone of this service was known as the Service de la rue Lecomte, or, as it was officially called, the North African Brigade (Brigade nord-africaine).

Rue Lecomte was, to a large extent, the result of one man's obsessive campaign to bring the lessons he had learned as a colonial official in Algeria to bear on the administration of North African immigrants in Paris. Pierre Godin, whom we met earlier, began his career in Algeria as a clerk and went on to become a police officer and eventually a sous-prefect. Godin believed that an understanding of the "native mentality" was essential to the proper management of the capital's North African populations, and indeed rue Lecomte was directed by a former official from the French administration in Algeria: Adolphe Gérolami, who had been chosen for his knowledge of the "Algerian 
Muslim."25 Although the Bureau de la rue Lecomte was described as a resource center for North African Muslim workers, it was primarily a site designed to monitor the movements and activities of the Maghrébin population in the city and suburbs. Godin, who was of course one of the Mosque's main proponents, explained in his report to the Paris City Council:

A recent and sensational crime - the murder of two poor women...by an Algerian Kabyle...has focused the anxious attention of public opinion on the invasion of France by foreign or colonial elements, especially North African emigrants. [Public opinion] is beginning to wonder if some prudent measures wouldn't be in order, to discipline, maybe even limit, this invasion. ... We do not know exactly how many Algerian or African natives [indigènes] there are in Paris. ... Algerian indigènes travel freely and thus it is very difficult to follow this errant work-force in its peregrinations. ${ }^{26}$

The Service de la rue Lecomte was designed to respond to this free-floating anxiety about the presence of these "timid men from the mountains" transformed into "urban workers" and living among the French. Godin minced no words about the service's dual purpose: to "monitor and aid" the city's North Africans. He presented it as a moral imperative, for "these 'primitives' are among us. These 'mountain dwellers,' these 'barbarians' heard civilization's call and are tasting the charms of the City. With them, old Africa opens itself up and comes to us. It is Islam, approaching."27 The equation of "old Africa" with "Islam" in this formulation is instructive. What is most important to note about rue Lecomte is the way its programs were structured around a conception of these workers as simultaneously Muslim and North African. For Godin and the other authorities involved in the management of North African immigrant populations, "Africa" arriving on France's doorstep was really the approach of Islam.

The rue Lecomte site was located in a former school building in the eastern part of the 17th arrondissement. Initially, it consisted only of a labor placement

25 Clifford Rosenberg, Policing Paris: The Origins of Modern Immigration Control between the Wars (Ithaca, NY: Cornell University Press, 2006), 155-157.

26 "Proposition tendant à créer à la Préfecture de Police une section d'affaires indigènes nord-africaines qui s'occupera de la situation matérielle et morale et de la police des indigènes nord-africains, resident ou de passage à Paris. Déposée par MM. Pierre Godin, Besombes, et Emile Massard, Conseillers Municipaux," Proposition no. 178, 20 December 1923. Conseil Municipal de Paris, Rapports et Documents 1923, Nos. 151-191.

Ibid. 
and information office for North African workers' use. North African immigrants to Paris were required to register their presence at the office and occasionally to renew their identity papers. Rue Lecomte employees also promised aid with locating jobs, translation, legal paperwork, the shipment of one's earnings to family in North Africa, and other services. The complex also featured a cafe, which, along with the other resources, was largely ignored by the city's Muslims, as Gérolami sadly reported to a colonial official visiting from Morocco. ${ }^{28}$ The following year, in 1926, the City Council inaugurated the dispensary, which provided basic care and minor surgery. Medical professionals concerned with public health noted with relief that the clinic also featured special services for those afflicted with tuberculosis and venereal diseases, which were thought to be endemic to North Africans. ${ }^{29}$ In 1927, an eighty-bed hostel, or foyer, also opened as part of the rue Lecomte site. Gérolami hoped to extend his and his institution's authority beyond the walls of the rue Lecomte complex and do a better job of winning the loyalty of the city's Muslim workers. Another foyer was built in the suburb of Gennevilliers, which featured a prayer room, "hammam and café," and dormitories, and the rue Lecomte's director hoped to see similar foyers develop all over the city and suburbs. Gérolami believed that his agency and other Parisian Muslim institutions needed to create deeper connections with the city's Muslim communities and that the best way to do this was through the creation of mutual aid societies, which would work through the idiom of Islam. He tried to launch a "fraternal association of... Muslims in Paris, a sort of mutual assistance society, whose first project would be the construction of the wall of the Muslim cemetery of Paris." ${ }^{30}$ Gérolami's Muslim mutual aid society, however, met with as little success as his café, for Muslims continued to rely on their own associations rather than pay a monthly membership fee to join rue Lecomte's association.

Managing North African immigrants thus revolved around two poles: social assistance and policing. The trio that oversaw Paris's "Muslim" institutions, Si Kaddour, Gérolami, and Godin, was implicated in providing the conditions for the "proper" observance of Muslim life cycle events, particularly illness and death. The Paris City Council and police were instrumental in managing endof-life issues for North Africans, religious or not, during this period. The links

28 Lt.-Col. Justinard, Rapport sur sa mission en France, novembre 1930, AMAEE K Afrique/ Questions Générales 1918-1940/32: Emploi de la main d'oeuvre indigène dans la Métropole, $1926-1928$.

29 See Max Hulman, "L’Hôpital Franco-Musulman de Paris et du département de la Seine," La Presse Médicale 74 (14 September 1935): 1443-1445.

$30 \quad$ Justinard, "Rapport." 
connecting the SAINA, the Mosque, and the Franco-Muslim Hospital in the eastern suburb of Bobigny were extremely close. ${ }^{31}$ The Interministerial Commission for Muslim Affaires (CIAM) was one of the agencies that influenced the decisions taken by this triumvirate. The cIAM pronounced itself in favor of standardized regulations concerning the burial of Muslims in the Paris region; the setting aside of plots in suburban graveyards, "where they can be buried according to their beliefs and rituals," in addition to the expensive Muslim area of the Père Lachaise public cemetery; the formation of an association to provide indigent Muslims with religious burials; and, finally, the creation of an Office of Muslim Beneficence. ${ }^{32}$ The question of Muslim cemeteries was thus considered at the same time that decisions about health care and foyers for North African workers were being made. The ciam dedicated a meeting early in 1931 to debating how and where a cemetery for Paris's Muslims could be created, with testimony from Si Kaddour, Pierre Godin, and Gérolami. The issue was raised when Si Kaddour addressed the Préfet de la Seine directly, asking that he support the establishment of such a site; he in turn consulted the minister of the interior about the legality of such an undertaking. Si Kaddour presented the issue as something that concerned Paris's Muslims "because of the religious character attached to Muslim funerals. If, in death, they find themselves far from Muslim lands, they attach an even greater value to having a cemetery reserved for members of their faith."33 The Préfet de la Seine's hesitation in the face of this request was based not only on his concerns about legality but also on fears that in giving $\mathrm{Si}$ Kaddour a positive response, "we would expose ourselves to reclamations in the same style from Protestants [and] Jews." ${ }^{34}$ Yet as $\mathrm{Si}$ Kaddour explained in person at the meeting, "As for the objections on legal grounds which have been put forward, they were also true for the Muslim Institute and the Paris Mosque, which were nevertheless created. Thus we need only follow an analogous procedure" to establish a cemetery. Godin's solution to this problem was to suggest that the Franco-Muslim Hospital contribute land for the creation of a Muslim burial ground, as hospitals serving particular populations could legally build cemeteries on their grounds. The ciAm accepted this compromise, and the burial ground was eventually constructed in Bobigny.

\footnotetext{
31 See Rosenberg, Policing Paris, 141.

32 Rapport de la CiAM, séance du 10 février 1927. ANOM 81F 834.

33 This letter, dated 9 December 1930, is cited by M. Augustin Bernard at the CIAM's meeting on 27 February 1931. See Procès-Verbal de la CIAM, 27 February 1931, Question 2: Demande de création d'un cimetière pour les Musulmans de Paris et de la region parisienne. ANOM 81F 834: Cimetières musulmans.

Ibid.
} 
In the debate over this issue, Si Kaddour was asked who would be buried in such a site. He responded that it would be primarily soldiers, "since the bodies of Muslim notables who die in Paris are usually repatriated to their country of origin by their families." Si Kaddour's assertion that a Muslim cemetery in Paris was of interest to Muslims the world over was an exaggeration, but it was certainly a point of interest to French diplomats and functionaries in the Muslim world who were concerned with the religious observances of the Muslim elite. As a French diplomat stationed in Cairo explained, although "the Orientals who travel to France belong to the fortunate classes who don't go to mosques," the Paris Mosque had still been used for the funerals of two Egyptians who, though not observant at all, still wanted a Muslim burial. He was strongly in favor of the creation of a Muslim cemetery, because although "a 'believer' can not pray, [and] he can be treated in a public hospital with no problem, ...he cannot face the idea of being buried right next to non-Muslims."35

While creating areas where Muslims could be buried according to the precepts of their religion was a priority for those making Muslim policy in the Paris region, their medical care was also a huge concern. As historian Clifford Rosenberg and others have shown, in the 1920 and 1930 s the French had great fears of venereal disease among the population of single North African men who arrived in France as laborers. Policies segregating this population to Muslim dispensaries and hospitals were based on these fears, yet were couched in the language of cultural sensitivity. The dispensary of the Mosque itself was formally placed under the control of the Office of Social Hygiene of the Préfecture de la Seine in 1928.

The real centerpiece of North African healthcare in Paris, however, was the Franco-Muslim Hospital of Bobigny, one of whose architects was none other than the Mosque's Maurice Mantout. The hospital was voted into existence by Paris's City Council on 11 July 1929 and came under the authority of the Département de la Seine in 1930. Its location was a source of great tension between the various Paris-area politicians involved in its creation, and it was eventually decided to construct it in the communist suburb of Bobigny as an attack on its leadership. ${ }^{36}$ Like the policing agencies, it was supposed to protect North African and French populations by isolating Muslim workers and providing them with separate services. During the period in which the hospital was conceived, constructed, and inaugurated, Paris's public health care system

\footnotetext{
35 Letter from Henri Gaillard to Aristide Briand, 21 March 1927. ANOM 81F 834.

36 See Neil MacMaster, "Imperial Façades: Muslim Institutions and Propaganda in Interwar Paris," in Promoting the Colonial Idea: Propaganda and Visions of Empire in France, ed. Tony Chafer and Amanda Sackur (New York: Palgrave, 2002).
} 
was in a disastrous state. The public hospitals served only Parisians whose incomes fell below a certain level, and its health care services were entirely free. Outdated and overpopulated, the city's hospitals were increasingly unable to cope with the demands of the city's population. In the face of these poor conditions, many local politicians objected to spending money on health care for immigrants, even though, statistically speaking, foreigners made up only a small percentage of the patients of the city hospitals overall.

The Franco-Muslim Hospital was designed to give North Africans access to a health care center big enough to cope with an increasingly large population (the Rue Lecomte and Mosque clinics had become too crowded). The arguments made in favor of this health care regime, which were echoed in the medical press, concerned not only anxieties about "African pathology which demands doctors and nurses with specialized education" but also social welfare concerns about a population that felt "unmoored, isolated" in French hospitals. North Africans treated in Paris's public hospitals "found none of the traditions and customs which are so important to them and to which they are so faithful. Everything, the staff, the other patients, was strange to them." ${ }^{37}$ The Franco-Muslim Hospital would allow them to feel at home again "during a time when, touched by illness, they are particularly sensitive." ${ }^{38}$ Although the hospital contained all of the most modern medical technologies, its façade was designed to signal its special North African character. The medical press was not insensitive to the display:

This monumental door, in pure mauresque style, produces a beautiful effect. ... It's very "local color," one finds oneself in a very evocative atmosphere. ... If one had to formulate a critique, it would be that it is too well done... a bit too luxurious for a clientele who, doubtless, will not appreciate it, nor understand it, nor take pleasure in it. ${ }^{39}$

Aside from its "Muslim" aesthetic, the daily administration of the hospital was structured around Muslim religious requirements. The statutes of the hospital decreed that a number of Arabic-speaking doctors, preferably those "familiar... with Muslim natives and their customs," would be recruited and that Arabicspeaking staff would receive bonuses. Freedom of religion would be respected within the hospital's walls, but "the Paris Mosque's imam or a Muslim clergyman designated by the Muslim Institute [would] have access to patients who

39 Hulman, “L'Hôpital Franco-Musulman de Paris," 1444. 
seek their assistance." Furthermore, the site would feature not only "a prayer room for the patients and Muslim personnel" but also a space for the "slaughter of animals according to Muslim ritual." 40 The hospital's Muslim personnel were given the day off on Muslim holidays, and during the month of Ramadan, patients' meals were served at sunset.

Although much care was taken to describe the hospital as a place designed to cater to Muslim religious needs, it was also a place to quarantine foreign bodies suspected of harboring dangerous diseases that might easily spread to French citizens. Or, as the president of the departmental council of the Seine explained at the hospital's inauguration, "We needed to protect, but also police, because undesirable individuals had been mixing with healthy elements."41 The full ambiguity of the French state's position lies in its attitude toward Muslim bodies: they were considered a danger to public health but were also taken seriously as having particular embodied religious practices that needed to be provided for in a hospital setting if patients were to have any hope of recovery. While those who celebrated the hospital's creation claimed that "the population truly appreciated" the special treatment the hospital afforded them, even if they could not fully understand the attention that went into its aesthetic planning, ${ }^{42}$ many North Africans did everything in their power to avoid receiving treatment at the Franco-Muslim Hospital. In 1937, for example, one third of admitted patients refused to be treated there. ${ }^{43}$ The special committee of the High Committee on the Mediterranean (Haut-Comité Méditerranéen, or НСM), a group of French experts on the Muslim world established under Léon Blum's Popular Front government, was disturbed to report that Muslims had to be forced to go to the Franco-Muslim Hospital against their will. The нсм's observers were surprised to find that "in spite of the excellence of the medical care, which incidentally demands a very significant budgetary contribution from the state, some North Africans prefer to be treated in other hospitals." ${ }^{44}$ A member of the Seine General Council went further in his observations of the missteps of the state's attempt to provide Muslims with appropriate health care. "I must say," Léon Mauvais explained, "that Arabs have come

40 Statuts de l'hôpital franco-musulman. Conseil général de la Seine, 9 July 1930.

41 Inaugural Speech, Augustin Beaud, Président du Conseil général de la Seine.

42 "L'Action charitable de la Ville de Paris et du département de la Seine," Le Plus Grand Paris 1 (February 1938).

43 See Rosenberg, Policing Paris.

44 Commission d'Études du HCM, "rapport conforme aux propositons de la sous-commission des lois sociales et assistance," 17 June 1937, AMAE K Afrique/1918-1940/Questions Générales. 
to complain that they have been forced to go to this Franco-Muslim hospital and that the Parisian hospitals did not want to admit them." Mauvais also noted that "some North Africans did not want to follow the special alimentary regime" used at the hospital "because they are now used to French customs, even [when it comes to food]."45 Immigrants' refusal to be segregated on the basis of religion suggests that they were fully aware that they were being denied access to the services available to everyone else, even as they were being offered special privileges. Their desire to be treated at French public hospitals may have stemmed in part from fears about the quality of care at the Franco-Muslim Hospital, but certain Muslims were also rejecting their involuntary assignation to the categories "Muslim," "Arab," and "North African." In other words, they were rejecting a regime that kept them outside of the boundaries of the French public sphere, supposedly for their own comfort, on the basis of their presumed religious identity.

\section{Conclusion}

It could be argued that in providing immigrant workers from majority Muslim countries with health care designed to respond to Muslim sensibilities or the means to celebrate major holidays at a mosque located in the center of the city, the French state was being more generous to its colonial subjects than it was to its metropolitan citizens (a charge often leveled against the founders of the Franco-Muslim Hospital, for example). Certain politicians working at the municipal and national levels truly believed that they were responding to a desperate need on the part of Muslim immigrant workers. Yet it is essential to remember that the discourse of providing Muslims with "special" medical or employment services masked the fact that they were kept in a parallel social universe, separated not only from the French but also from other immigrants. Having defined their vision of French Islam in the form of the Mosque, the next step for those involved in its administration was to use that "Islam" as the medium for all interactions with North African immigrants, thus reducing their multifaceted socio-cultural lives to a single element. The religious sentiments of working-class immigrants from the Maghrib were dismissed as unorthodox at best and illegitimate at worst.

The decision to structure social assistance programs for North African immigrants along Muslim lines set the pattern for the state's interaction with these 
communities. Rosenberg argues that by "treating North Africans so differently from other immigrants, by segregating them and subjecting them to an often brutal surveillance regime, republican authorities helped entrench what had been an unexceptional anti-'Arab' sentiment and reinforced a critical distinction between nationality and citizenship." ${ }^{\prime 6}$ While not disagreeing with this conclusion, I would suggest instead that the separate regime designed for North African immigrants, particularly in the case of Algerians who were in fact French nationals, was more significant in that it legitimized segregation on religious grounds in the name of cultural sensitivity. The local, national, and colonial politicians involved in the creation of the mosque, surveillance and medical apparatus that policed the capital's North Africans acted out of complex motives; some of them sincerely believed that they were providing their colonial workers with services they wanted. Judging their motives, however, is less important than recognizing the fact that French politicians believed Islam's embodied demands to be such that Muslims required separate hostels and hospitals and could not be assimilated into the larger immigrant population, let alone the French population. Thus in writing the long history of Islam's presence in metropolitan modern France, it is crucial to recognize the importance of the collaboration between the French state and $\mathrm{Si}$ Kaddour. While their strategic use of French Islam and its incarnation in these three institutions was contested by many North African immigrants, it nevertheless indelibly shaped the state's relationship with Muslims in France for the rest of the century.

\section{Bibliography}

\section{Archival Sources}

$\mathrm{AMAE}=$ Archives du Ministère des Affaires étrangères et européennes Afrique. $\mathrm{AN}=$ Archives nationales. ANOM $=$ Archives nationales d'outre-mer. APP $=$ Archives de la Préfecture de Police. SHAT $=$ Société historique de l'armée de terre.

\section{Primary Sources}

Bourdarie, Paul. "L'Institut Musulman et la Mosquée de Paris." La Revue Indigène (October-November 1919).

\footnotetext{
$46 \quad$ Rosenberg, Policing Paris, 198.
} 
Buchet, Georges. “La Mosquée de Paris." En Terre d'Islam 34 (1930): 28-32.

Descamps, Henri. L'Architecture moderne au Maroc. Paris: Librairie de la Construction moderne, 1931.

Goissaud, Antony. "L'Institut musulman et la Mosquée de Paris." La Construction moderne 3 (2 November 1924): 50-55.

Hulman, Max. “L’Hôpital Franco-Musulman de Paris et du département de la Seine." $L a$ Presse Médicale 74 (14 September 1935): 1443-1445.

L'Illustration. "Un décor d'Orient sous le Ciel de Paris." 26 November 1926.

Justinard, Pierre. "La Mosquée de Paris." MA thesis, Ecole nationale de la France d'outre-mer, 1944.

Madras, Didier and Boris Maslow. Fès, Capitale artistique de l'Islam. Casablanca: Editions Paul Bory, 1948.

Le Plus Grand Paris. "L'Action charitable de la Ville de Paris et du département de la Seine." 1938.

Revue Médico-Sociale. "L’Hôpital Franco-Musulman.” (1935): 134-135.

Weiss, René. Récéption à l'Hôtel de Ville de Sa Majesté Moulay Youssuf, Sultan du Maroc, Inauguration de l'Institut Musulman et de la Mosquée de Paris. Paris: Imprimerie Nationale, 1927.

\section{Secondary Sources}

MacMaster, Neil. "Imperial Façades: Muslim Institutions and Propaganda in Interwar Paris." In Promoting the Colonial Idea: Propaganda and Visions of Empire in France, ed. Tony Chafer and Amanda Sackur. New York: Palgrave, 2002.

Rosenberg, Clifford. Policing Paris: The Origins of Modern Immigration Control between the Wars. Ithaca, NY: Cornell University Press, 2006.

Sherman, Daniel. The Construction of Memory in Interwar France. Chicago: University of Chicago Press, 1999.

Wilder, Gary. The French Imperial Nation-State: Negritude and Colonial Humanism between the Two World Wars. Chicago: University of Chicago Press, 2005.

Wright, Gwendolyn. The Politics of Design in French Colonial Urbanism. Chicago: University of Chicago Press, 1991. 